\title{
Die klank van aanbidding
}

\begin{abstract}
Book Title:
The Sound of Worship: Liturgical Performance by Surinamese Lutherans and Ghanaian Methodists in Amsterdam
\end{abstract}

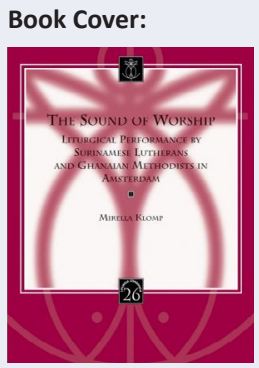

Editor:

Mirella Klomp

ISBN:

978-90-429-2571-7

Publisher:

Peeters Pers, Leuven; 2011, $€ 59.00 *$

* Book price at time of review

Review Title:

Die klank van aanbidding

\section{Reviewer:}

Cas Wepener ${ }^{1}$

\section{Affiliation:}

${ }^{1}$ Department of Practica

Theology, University of

Pretoria, South Africa

Email:

cas.wepener@up.ac.za

Postal address:

Private Bag X20, Hatfield

0028, South Africa

How to cite this book review: Wepener, C., 2013, 'Die klank van aanbidding', Verbum et Ecclesia 34(1), Art. \#850, 1 page. http://dx.doi. org/10.4102/ve.v34i1.850

\section{Read online:}

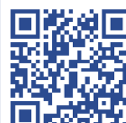

Scan this QR code with your smart phone or mobile device to read online. 'n Mens sou tereg die vraag kon vra waarom 'n liturgiewetenskaplike boek oor aanbidding deur Surinamese Lutherane en Ghanese Metodiste in Amsterdam vir 'n Suid-Afrikaanse teologiese tydskrif geresenseer word. Kyk en luister jy egter na die opnames van hierdie aanbidding op die $\mathrm{CD}$, wat saam met die boek aangebied word, is jou vraag onmiddellik beantwoord. Ja, die taal is inderdaad vreemd. Selfs die voorkoms van die mense toon duidelik hulle is nie van hier nie. Wat wel dadelik herkenbaar is, is die klank van die aanbidding.

Jy dink by jouself: Ja, dit is opnames wat in die suidooste van Amsterdam gemaak is, maar desnieteenstaande ken ek hierdie klank. Die Surinaamse aanbidding klink baie soos die klank van eredienste wat ekself in Maitland, Kaapstad, gelei het en wat bygewoon is deur erediensgangers uit uiteenlopende agtergrond, terwyl die Ghanese eredienste se klank vir enige Suid-Afrikaner dadelik herkenbaar is as afkomstig van ons kontinent. En die 'klank van aanbidding' as 'n konsep, ofte wel die 'sound of worship', is juis die besondere bydrae van hierdie boek van Mirella Klomp wat gebaseer is op haar doktorale navorsing oor die onderwerp. Die outeur begin met ' $n$ verhaal van 'n persoonlike, minder positiewe, ofte wel slegte, belewenis van ' $n$ erediens wat sy met ' $n$ vriend bygewoon het. Dis die punt: meer as slegs die orrelklanke of koormusiek of handeklap van aanbidders, is dit die somtotaal van klank in die liturgie wat mense tuis laat voel of hulle juis afskrik. En juis daarom, nog veel meer as slegs die herkenbaarheid van die aanbidding, is die uiteindelike konklusies waartoe die studie kom rakende kruiskulturele aanbidding van belang in 'n Suid-Afrikaanse multikulturele konteks.

Die outeur se konseptuele verbreding binne die liturgiewetenskap van tradisionele konsepte soos liturgiese musiek tot 'n veel meer omvattende 'klank van aanbidding' is 'n reusebydrae tot die veld. Die skuif in fokus is egter geensins sonder implikasies nie en 'n tradisionele benadering tot die onderwerp sal gewoon nie genoegsaam wees nie. Daarom volg die outeur 'n multidissiplinêre benadering wat, onder andere, die gebruikmaking van liturgiese musikale etnografie insluit om sodoende die totale liturgiese gebeure as 'performance' te kan bestudeer. In lyn met hierdie benadering binne die veld bestudeer die navorser dus die werklik uitgevoerde liturgie asook die volle omvang daarvan met betrekking tot die klank van aanbidding.

En dít doen sy met integriteit en deursigtigheid met betrekking tot haar werkswyse. Juis die aandag wat sy afstaan om vir die leser in kaart te bring hoe die data gekollekteer, gekodeer en geanaliseer is, is een van die groot pluspunte van hierdie studie. Dit getuig van 'n sterk wetenskaplike inslag en strewe na eerlikheid binne 'n doelbewus gekose, kwalitatiewe werkswyse.

'n Ander belangrike bydrae van die boek is die feit dat die teoretiese besinning van groot waarde kan wees vir liturgiese navorsing in Suid-Afrika. In die geheel gesien, bestaan die boek uit 'n grondige teoretiese en metodologiese ondersoek, daarna die twee gevallestudies, en dan eindig dit met ' $n$ teologiese evaluering.

Ten slotte kan opgemerk word dat die boek 'n publikasie van hoë gehalte is wat gemik is op 'n akademiese mark, maar desnietestaande aangenaam is om te hanteer met kleurfoto's van die aanbidding, asook die reeds vermelde CD wat die leser nog nader neem na die 'klank van aanbidding' in die suidooste van Amsterdam. As nie alleen liturgis nie, maar ook liturg op gereelde basis, het hierdie bydrae van Mirella Klomp my opnuut laat nadink oor die klank van ons liturgie en hoe dié klank mense se geloof beliggaam en die moontlikheid dat Christus in die liturgie ontmoet word, aanhelp of verhinder. 